\title{
Prevalence and Clinical Features of Body Dismorphic Disorder on Psychiatric Inpatients: A Cross-sectional Study in Edirne/TURKEY
}

\author{
Yatarak Tedavi Gören Psikiyatri Hastalarında Beden Dismorfik Bozukluğu Yaygınlı̆ı ve \\ Özellikleri: Edirne/TÜRKIYE'de Kesitsel Bir Araștırma
}

\author{
Yasin Tașdelen', Yüksel Kıvrak², Mehmet Așoğlư3, Rugül Köse Çınar ${ }^{4}$ Ercan Abay ${ }^{5}$ \\ ${ }^{1}$ Edremit State Hospital, Department of Psychiatry, Ballkesir; ${ }^{2}$ Kafkas University, Faculty of Medicine, Department of Psychiatry, \\ Kars; ${ }^{3}$ Haran University, Faculty of Medicine, Department of Psychiatry, Urfa; ${ }^{4}$ Trakya University, Faculty of Medicine, Department of \\ Psychiatry, Edirne; ${ }^{5}$ Kemerburgaz University, Faculty of Medicine, Department of Psychiatry, İstanbul, Turkey
}

\begin{abstract}
Aim: Body dysmorphic disorder $(B D D)$ is characterized by the presence of an imaginary defect of oneself and an increased mental occupation which causes either an impairment in functionality or clinical distress. The aim of our study was to detect BDD prevalence and its clinical features in hospitalized psychiatric patients.

Material and Method: Hospitalized patients in our clinics were evaluated. All the patients in our study were evaluated by using a questionnaire that was prepared in accordance with the $B D D$ literature by the authors, a sociodemographic data form, Structured Clinical Interview for DSM-IV Axis I Disorders (SCID-I) and Structured Clinical Interview for Axis II Disorders (SCID-II).

Results: $B D D$ prevalence was found to be $7 \%$ in hospitalized psychiatric patients. It was also observed that all patients with $B D D$ had self-image anxiety, had mirror checking behaviour, tended to camuflage the perceived defect, spent more than one hour in selfimage anxiety and had personality disorders. Howeve, none of the $B D D$ patients ever mentioned any symptoms related to $B D D$ unless they were asked and none of them had been diagnosed with $B D D$ by the psychiatric team who were treating them.

Conclusion: $B D D$ is relatively common in hospitalized psychiatric patients. Therefore most $B D D$ patients are not diagnosed. $B D D$ diagnosis rate might be improved by questioning $B D D$ as well as inspecting self-image anxiety.
\end{abstract}

Key words: body dysmorphic disorder; prevalence; inpatients; body image; Turkey

ÖZET

Amaç: Beden dismorfik bozukluğu (BDB), klinik olarak belirgin sıkıntı yaratan veya ișlevselliğin önemli alanlarında bozukluğa yol

Yüksel Kivrak, Kafkas Üniversitesi Tip Fakültesi, Psikiyatri Klinï̆i, Kars - Türkive, Tel.04742251193Email.ykivrak21@gmail.com

Geliş Tarihi: 03.09.2016 • Kabul Tarihi: 18.10.2016 açan, kișinin görünüșündeki hayali bir kusur ile artmıș zihinsel uğrașın varlığı ile karakterizedir. Yatarak tedavi gören psikiyatri hastalarında BDB yaygınlığını ve klinik özelliklerini belirlemeyi amaçladık.

Materyal ve Metot: Kliniğimizde çeșitli nedenlerle yatarak tedavi gören hastalar değerlendirildi. Çalıșmaya katılan her hasta tarafımızdan hazırlanan sosyodemografik veriler ve BDB ile ilgili sorulardan olușturduğumuz anket formu, Structured Clinical Interview for DSM-IV Axis I Disorders DSM-IV Eksen I Bozuklukları Için Yapılandırılmıș Klinik Görüșme (SCID-I) ve II. Eksen Kișilik Bozuklukları Için Yapılandırılmıș Klinik Görüșme (SCID-II) kullanılarak değerlendirildi.

Bulgular: Yatarak tedavi gören psikiyatri hastalarında BDB yaygınıІ̆̆ını \%7 olarak tespit edildi. BDB'li hastaların tamamında görünüm endișesi, ayna kontrolü, kusurlu bulduğu bölgeyi gizleme davranıșı, görünüm endișesi ile ilgili olarak bir saatten fazla zaman harcama davranıșı ve kișilik bozukluğu olduğu, ayrıca hiçbir BDB'lu hastanın sorulmadıkça $B D B$ ile ilgili belirtiyi söylemediği ve hiç birinin $B D B$ teșhisinin tedaviyi yürüten ekipçe koyulamadığı bulundu.

Sonuç: Yatarak tedavi gören pskiyatri kliniği hastalarında BDB nispeten yaygın bir hastalıktır. Bu duruma rağmen teșhis edilememektedir. Bdb ye yönelik görünüm endișesi yanında kolayca sorgulanabilecek sorularla inceleme BDB teșhis oranını artırabilir.

Anahtar kelimeler: beden dismorfik bozukluğu; yaygınlık; hastane yatarak tedavi; beden imajı, Türkiye

\section{Introduction}

Body dysmorphic disorder (BDD) is a psychological disorder which includes anxiety and obsession about a perceptional body defect. While men tend to have anxieties about their reproductive organs, body structure and hair, women tend to have anxieties about their skin, stomach and weight ${ }^{1,2}$. These defects are usually not really present or present but hardly noticable. However 
this kind of concerns affect functionality in various areas such as social and work areas and cause distress and anxiety. BDD was first described as "dysmorphophobia" by Emil Kraepelin in the last century. Although BDD was not included in the first and the second editions of the Diagnostic and Statistical Manual of Mental Disorders, in the third edition which was published in 1980, BDD was defined as "dysmorphophobia" under the atypical somatoform disorders category. It was included in the somatoform disorders category until the DSM-V was published. Since BDD had similarities to the Obsessive-Compulsive Disorder (CAD), it was defined under the OCD and related disorders category in DSM-V ${ }^{3-5}$.

Patients with BDD tend to be ashamed of their status. They are not persuaded by others' comments ${ }^{1}$. They tend to be reluctant to seek psychiatric help due to their anxieties about self-image and also economical problems, shame, stigma and concerns about the benefits of the treatment prevent their treatment seek $^{1,6}$. About one third of BDD patients lack insight and their body perceptions tend to be delusional. Due to the lack of insight, these patients tend to look for non-psychiatric solutions ${ }^{2,7}$. Most of them undergo unnecessary dermatological and cosmetic surgical interventions ${ }^{8}$. This disorder causes a decrease in the overall life quality. The physical health subscale scores of BDD patients are usually lower than the mean population score. Their mental health subscale scores are usually lower than patients with acute heart attack, depression, OCD, bipolar disorder, schizophrenia and diabetes 9 . Most BDD patients are unable to continue their daily routines such as going to work or school. Their life appreciation and satisfaction scores are usually lower than patients with major depression, chronic major depression, dysthymia, premenstrual dysphoric disorder, OCD, social phobia, panic disorder and post-traumatic stress disorder (PTSD) $)^{9,10}$. They have higher rates of hospitalization and suicide. About $80 \%$ of BDD patients develop suicidal thoughts and about $25 \%$ attempt to commit suicide. Completed suicide risk of BDD patients are higher than patients with eating disorders, major depressive disorder and bipolar disorder and even 40 times higher than the mean population rate ${ }^{11}$.

BDD prevalence varies between $2.4 \%$ and $1.7 \%$. BDD prevalence in outpatients and hospitalized patients are $6.7-1.8 \%$ and $16.0-13.1 \%$, respectively ${ }^{3}$. This rate may be as high as $25 \%$ in plastic surgery and dermatology departments ${ }^{1,3,12,13}$. In psychiatric outpatients clinics BDD prevalence is $3.2-0.8 \%{ }^{14-16}$. As far as we know, there are only 4 studies about the prevalence of BDD in hospitalized psychiatric patients. All of these studies were performed in either Europe or the USA. There are no studies on this subject in Turkey. In these 4 studies prevalence rates vary between $16 \%$ and $1.9 \%$. This high range in prevalence might be both due to cultural differences and methodological differences ${ }^{8,16-19}$. In our study we both aimed to evaluate the prevalence in Turkey and decrease the literatural ambiguity.

\section{Material and Method}

\section{Study Group}

Study group consisted of hospitalized patients in the Psychiatry Department of Trakya University Medicine Faculty, Edirne, TURKEY. Trakya University Medicine Faculty Hospital is a third grade hospital which serves in educational, research and treatment areas in a wide populated region. Psychiatric patients who apply to our department, are first examined in the outpatients clinic and hospitalized if needed. Upon their hospitalization, patients are re-evaluated by a psychiatry specialist and prescribed relevant treatment. At least once a week all the hospitalized patients are re-evaluated by a Psychiatric Committee that includes psychiatry lecturers and treatments might be re-arranged on their advice.

The inclusion criterias of our study were being hospitalized and being volunteer to participate in the study. Patients older than 65 years of age and patients younger than 18 years, patients who were either in acute ma$\mathrm{nia} / \mathrm{manic}$ exacerbation or psychosis phase/psychotic exacerbation and patients who were unable to understand the questionnaire or unable to complete the interview due to mental retardation were excluded from the study.

\section{Evaluation Tools}

Data Evaluation Form: A questionnaire which was developed by the authors of the study in order to evaluate sociodemographic data and BDD related symptoms of patients and their families.

SCID-I/CV (Structured Clinical Interview for DSMIV/Clinical Version): It was developed by First et al. in order to diagnose axis disorders in DSM-IV ${ }^{20}$. Its use is convenient in patients whose age are 18 years or older. It is administrated by an interviewer ${ }^{20}$. Validity 
and reliability of the Turkish language translation is available $^{21}$.

SCID-II (Structured Clinical Interview for DSMIII-R Personality Disorders): It was developed by Spitzer et al. ${ }^{22}$ in order to diagnose Axis-II disorders in accordance with the DSM-III-R. It is an half structured test. Patient fills the form first, then the interviewer asks the questions, the answers of which are positive or suspicious. The validity and reliability of the Turkish language translation is available ${ }^{23}$.

\section{Procedure}

Institutional Ethics Committee approval was gained for the study. Our study was performed in the psychiatric patients who were hospitalized in the Psychiatry Department of Trakya University Medicine Faculty, (Edirne, TURKEY) between 15.01.201215.07.2012. During this period 160 patients were hospitalized. Hospitalization diagnosis was recorded as the Psychiatric Committee's diagnosis. Patients were called into the examination room and informed about the study. Psychiatric interview was performed with patients who volunteered to participate in the study and they were asked to fill the forms. 40 patients were excluded from the study as they did not meet the inclusion criterias and 15 patients refused to participate in the study. Thus, 100 patients in total were included in the study.

Statistical analyses were performed using the STATISTICA AXA Software, Version 7.1. Frequency (n) and percentage (\%) parameters were used to define the categorical data and mean $\pm S D$ was used to define the continuous data. Comparisons between groups were performed using Chi-Square and Fisher's exact test for the categorical data and Mann Whitney U test for the continuous data. Statistical significance was determined as $\mathrm{p}<0.05$.

\section{Results}

Average age of in-patients is $37.4 \pm 10.6$, and $51 \%$ of them is female, whereas $49 \%$ is male. And, $64 \%$ of them is married while $36 \%$ is single; $2 \%$ is literate, $29 \%$ is primary school graduate, $32 \%$ has elementary school degree, 28\% has high school, 6\% has associate degree and $3 \%$ has bachelor degree (Table 1). Most diagnosed disorders in in-patients are bipolar affective disorder, acute manic attack, major depressive disorder, psychotic depression; alcoholism and schizophrenia, also, percentage of others are seen as $3 \%$ and less (Table 2).

Age, body mass index and hospitalization number of patients with and without BDB comorbidity are found $36.6 \pm 13.4,37.4 \pm 10.5, p=0.607 ; 23.7 \pm 4.5,26.5 \pm 5.8$, $\mathrm{p}=0.337 ; 1.86 \pm 1.46,1.88 \pm 1.86, \mathrm{p}=0.942$, respectively.

Patients with and without BDB comorbidity; when compared according to gender (male 6.1\%, 93.9\%; female $7.8 \%, 92.2 \% ; \mathrm{p}=1000$ ), place of birth (city $8.3 \%$, 91.7\%; district $10.8 \%, 89.2 \%$; village $100 \%$; $\mathrm{p}=0.282$ ), marital status (single 8.3\%, 91.7\%; married 6.3\%, 93.8, $\mathrm{p}=0.700)$ no difference is found. However, in terms of appearance concerns $(100,0, \mathrm{p}<0.001)$, mirror control $(100,0, p<0.001)$, behavior of masking the defected part $(100,0, p<0.001)$ differences are found.

In terms of personality disorders, all of BDB patients were diagnosed with personality disorders whereas $59.1 \%$ of other patient group without BDB comorbidity is diagnosed with personality disorder $(p<0.05)$. The personality disorders distribution in both groups demonstrated no difference $(\mathrm{p}<0.05)$ (Table 1$)$. In BDB comorbidity group, $71.4 \%$ of patients were spending more than 3 hours in consequence of appearance concern; whereas, one person $(1.1 \%)$ in other group without comorbidity was spending more than one hour.

According to BDB comorbidity, when amount of daily consumed time in favor of appearance concern is compared between groups, reported as statistically significant $(\mathrm{p}<0.05)$ (Table 3$)$.

\section{Discussion}

This study is the first study that shows the BDD prevalence in hospitalized psychiatric patients in a Turkish clinic is $7 \%$. It is also the 5th study on this subject throughout the world and the 1st one performed in a mostly muslim country.

Our study confirmed that BDD is often neglected even by the psychiatrists. Diagnosis rates tend to improve if the patients are questioned about it. In our study all the patients with BDD had self-image anxiety, had mirror checking behaviour, tended to camuflage the perceived defect, tended to spend more than 1 hour about self-image anxiety and had personality disorders. None of the patients gave any information about BDD unless when they were questioned about BDD. Hospitalized patients were diagnosed after questioning about BDD. 
Table 1. Demographic data of inpatients

\begin{tabular}{llcc}
\hline & & Frequency (n) & Percentage (\%) \\
\hline Gender & Female & 51 & 51 \\
& Male & 49 & 49 \\
\multirow{5}{*}{ Educitial Status } & Married & 64 & 64 \\
& Single & 36 & 36 \\
& Literate & 2 & 2 \\
& Primary School & 29 & 29 \\
& Secondary School & 32 & 32 \\
& High School & 28 & 28 \\
& Collage & 6 & 6 \\
& Bachelor's Degree & 3 & 3 \\
\hline
\end{tabular}

Table 2. Distribution of hospitalization diagnoses

\begin{tabular}{lcc}
\hline Diagnoses & $\mathrm{n}$ & $\%$ \\
\hline Psychotic depression & 10 & 10 \\
Generalized anxiety disorder & 2 & 2 \\
Bipolar disorder acute mania & 33 & 33 \\
Schizophrenia & 9 & 9 \\
Atypical psychosis & 1 & 1 \\
Major depression & 15 & 15 \\
Schizoaffective disorder & 3 & 3 \\
Post traumatic stress disorder & 1 & 1 \\
Bipolar disorder depressive attack & 1 & 1 \\
Alcohol dependence & 10 & 10 \\
Alcohol abuse & 1 & 1 \\
Drug dependence & 2 & 2 \\
Anorexia nervosa & 2 & 2 \\
Obsesive compulsive disorder & 2 & 2 \\
Adjustment disorder & 1 & 1 \\
Schizophrenia+body dysmorphic disorder & 3 & 3 \\
Alcohol dependence + body dysmorphic disorder & 1 & 1 \\
Bipolar disorder acute mania+ body dysmorphic disorder & 1 & 1 \\
Major depression+body dysmorphic disorder & 1 & 1 \\
Somatoform disorder+body dysmorphic disorder & 1 & 1 \\
Total & $\mathbf{1 0 0}$ & $\mathbf{1 0 0}$ \\
\hline
\end{tabular}

Table 3. Comparison of patients with and without BDB comorbidity, in terms of time spent more than 1 hour due to appearance concern and personality disorder

\begin{tabular}{lccc}
\hline & \multicolumn{2}{c}{ BDB comorbidity } & $p$ \\
\cline { 2 - 2 } & Negative $\mathrm{n}(\%)$ & Positive $\mathrm{n}(\%)$ & \\
\hline Personality disorder & & & \\
$\quad$ Negative & $38(100)$ & $0(0)$ & 0.042 \\
Positive & $55(88.7)$ & $7(11.3)$ & \\
Time spent & & & \\
Negative & $92(97.9)$ & $2(2.1)$ & $<0.001$ \\
Positive & $1(16.7)$ & $5(83.3)$ & \\
\hline
\end{tabular}

BDD: Body dysmorphic disorder
Our study has many similarities and differences to the previous studies. In the American studies BDD prevalence was found to be $12.9-11 \%$, in the German and the British studies the prevalence rates were $1.9 \%$ and $5.8 \%$, respectively ${ }^{8,16-18}$. Our findings are lower than the American studies whereas they are in accordance with the British study. However, the German study's prevalence rate of $1.9 \%$ is much more lower than ours. These differences might be due to a few reasons. In the first place, the number of the study groups are different. In the second place these differences might be resulting from the methodological differences. In the third place, it might be resulting from the different range of diagnosis for hospitalization. Cultural differences may also be playing a role.

We consider it as an interesting issue that none of the patients in our study were diagnosed with BDD, although they had been examined by all the psychiatrists in our department. Whereas, this issue is also in accordance with the current literature. Studies in the current literature show that BDD is often neglected. In the study of Conroy et al. only one patient was able to be diagnosed by the first treating physician. In the studies of Grant et al. and Kollei et al. none of the physicians were able to diagnose $\mathrm{BDD}^{16-18}$. In their study Dyl et al. showed that BDD in hospitalized patients is not only frequent in adult patients but also frequent in adolescents ${ }^{24}$. Their study was performed in $208 \mathrm{pa-}$ tients, $6.7 \%(n=14)$ of them had definite or possible BDD diagnoses but only one physician patient was able to detect BDD in only one patient.

In our study we found that all of the patients with BDD had self-image anxiety, mirror checking and camuflaging behaviours. We suggest that our findings are important since it might be useful to question mirror checking and camuflaging behaviours as well as questioning the self-image anxiety. Therefore it is not possible to claim that these findings are pathognomonic for BDD. The possibility of false positivity should also be kept in mind. A recently published study supports this claim. In their study Veale et al. evaluated the use of self-image anxiety as a tool for screening in England in 2005 . Their results showed that in 95 out of 432 patients (22\%) self-image anxiety was present but other BDD diagnosis criterias were not covered. It was suggested that questioning self-image anxiety could lead to false positive results ${ }^{8}$. Our study supports this claim. In our study all the patients with BDD had self-image anxiety but also 12 out of the $81(14.8 \%)$ patients who 
were not meeting the BDD diagnosis criteria, had selfimage anxiety. Our results suggest that questioning the self-image anxiety might lead to false positive BDD diagnosis. We believe that further studies with larger study groups would be useful to determine the screening tools.

According to our study, all the BDD patients had at least one personality disorder. Our results are not relevant with other BDD prevalence studies in hospitalized patients. In 2 previous American studies this rate was found as $0 \%$ and $1 \%$, respectively ${ }^{17,18}$. In the British study only 4 out of 435 hospitalized patients were diagnosed with personality disorders ${ }^{8}$. Since there were 25 BDD patients in their study, their rate of concurrent personality disorders is lower than our rate. This difference might be resulting from our study design in which we used structured clinical interviews to diagnose personality disorders. It is also possible that researchers in the previous studies might have neglected personality disorders since they did not specially question it.

We believe that our results might have some benefits. First of all, we suppose that our findings would be useful for clinical psychiatrists. Since BDD is hard to diagnose unless questioned specially, it would be useful to question outclinics patients as well as the hospitalized ones. Secondly, our findings might be important for psychiatric academicians and medicine lecturers. During psychiatry education it might be emphasized that BDD is easily neglectable and must be questioned specially. It might also be important for clinical cosmeticians. Their awareness of BDD and its easily neglectability, might lead them to consult psychiatrists. Last of all, our study might be helpful for psychiatric researchers. Althrough we have found that all the patients with BDD had mirror checking and camuflaging behaviours, tended to spend more than 1 hour in selfimage anxiety and had personality disorders, it is not clear whether these findings apply to all geographic regions and all cultures. Further validity studies in other geographic regions and cultures would help better diagnose the disease.

Our study has some limitations. One of these limitations is the small number of our study group. But study sample size might not be an important issue considering the similar sized previous studies which had 100 and 101 patients, respectively ${ }^{17,18}$. The second limitation of our study is that it was performed in just one region and in a third grade hospital. Therefore it is possible to claim that our study is not representing the status in other regions and other hospitals. Our third limitation is only evaluating the BDD diagnosis without evaluating its severity. It would be useful to perform further studies without these limitations.

In conclusion, BDD was not diagnosed in any of our patients during the first examinations and all our BDD patients had mirror checking behaviour, tended to camuflage the perceived defect and spent more than one hour with self-image anxiety and all had at least one personality disorder. We believe that our study will be beneficial both to the literature and the clinical practice. There are a few reason for our claim. In the first place our study is the 5th study worldwide and the 1st study in Turkey on this subject. In the second place, it was performed in a mainly Muslim country. In the third place, our findings suggest that all the BDD patients have mirror checking and camuflaging behaviours and tend to spend more than one hour in selfimage anxiety and have a personality disorder.

\section{Conflict of Interest}

None

\section{Acknowledgement}

Our study was not financially supported by any institutions or foundations. Study was performed with authors' personal resources.

\section{References}

1. Fang A, Wilhelm S. Clinical features, cognitive biases, and treatment of body dysmorphic disorder. Annu Rev Clin Psychol 2015;11:187-212.

2. Phillips KA. The Presentation of Body Dysmorphic Disorder in Medical Settings. Prim Psychiatry 2006;13(7):51-9.

3. Fang A, Matheny NL, Wilhelm S. Body dysmorphic disorder. Psychiatr Clin North Am 2014;37(3):287-300.

4. Sadock BJ, Sadock VA, MD DPR. Kaplan and Sadock's Synopsis of Psychiatry: Behavioral Sciences/Clinical Psychiatry. Eleventh edition. LWW; 2014. p.1472.

5. Association AP. Diagnostic and Statistical Manual of Mental Disorders, 5th Edition: DSM-5 5 edition. Washington, D. C.: American Psychiatric Publishing; 2013. p.991.

6. Marques L, Weingarden HM, Leblanc NJ, Wilhelm S. Treatment utilization and barriers to treatment engagement among people with body dysmorphic symptoms. J Psychosom Res 2011;70(3):286-93.

7. Phillips KA. Psychosis in body dysmorphic disorder. J Psychiatr Res 2004;38(1):63-72. 
8. Veale D, Akyüz EU, Hodsoll J. Prevalence of body dysmorphic disorder on a psychiatric inpatient ward and the value of a screening question. Psychiatry Res 2015;230(2):383-6.

9. Phillips KA. Quality of life for patients with body dysmorphic disorder. J Nerv Ment Dis 2000;188(3):170-5.

10. Phillips KA, Menard W, Fay C, Pagano ME. Psychosocial functioning and quality of life in body dysmorphic disorder. Compr Psychiatry 2005;46(4):254-60.

11. Phillips KA. Suicidality in Body Dysmorphic Disorder. Prim Psychiatry 2007;14(12):58-66.

12. Conrado LA, Hounie AG, Diniz JB, Fossaluza V, Torres AR, Miguel EC, et al. Body dysmorphic disorder among dermatologic patients: Prevalence and clinical features. J Am Acad Dermatol 2010;63(2):235-43.

13. Alavi M, Kalafi Y, Dehbozorgi GR, Javadpour A. Body dysmorphic disorder and other psychiatric morbidity in aesthetic rhinoplasty candidates. J Plast Reconstr Aesthetic Surg 2011;64(6):738-41.

14. Vinkers DJ, van Rood YR, van der Wee NJA. Prevalence and comorbidity of body dysmorphic disorder in psychiatric outpatients. Tijdschr Psychiatr 2008;50(9):559-65.

15. Zimmerman M, Mattia JI. Body dysmorphic disorder in psychiatric outpatients: recognition, prevalence, comorbidity, demographic, and clinical correlates. Compr Psychiatry 1998;39(5):265-70.

16. Kollei I, Martin A, Rein K, Rotter A, Jacobi A, Mueller A. Prevalence of body dysmorphic disorder in a German psychiatric inpatient sample. Psychiatry Res 2011;189(1):153-5.
17. Grant JE, Kim SW, Crow SJ. Prevalence and clinical features of body dysmorphic disorder in adolescent and adult psychiatric inpatients. J Clin Psychiatry 2001;62(7):517-22.

18. Conroy M, Menard W, Fleming-Ives K, Modha P, Cerullo H, Phillips KA. Prevalence and clinical characteristics of body dysmorphic disorder in an adult inpatient setting. Gen Hosp Psychiatry 2008;30(1):67-72.

19. Veale D, Gledhill LJ, Christodoulou P, Hodsoll J. Body dysmorphic disorder in different settings: A systematic review and estimated weighted prevalence. Body Image 2016;18:168-86.

20. First MB, Spitzer RL, Gibbon M, And Williams, Janet BW. Structured clinical interview for DSM-IV clinical version (SCID-I/CV). Washington DC. American Psychiatric Press; 1997.

21. Özkürkçügil A, Aydemir Ö, Yıldız M, et al. IV E. DSM-IV Validity and Reliability of the Turkish Translation of Structured Clinical Interview for Axis Disorders. İlaç ve Tedavi Derg 1999; 12(4):233-6.

22. Spitzer RL, Williams JBW, Gibbon M, et al. Manual for the structured clinical interview for DSM-III-R personality disorders. Wash DC 1990;7.

23. Coşkunol H, Bağdiken I, Sorias S. Validity of SCIDII for personality disorders 28th National Psychiatry Congress Ank 1992.

24. Dyl J, Kittler J, Phillips KA, Hunt JI. Body dysmorphic disorder and other clinically significant body image concerns in adolescent psychiatric inpatients: prevalence and clinical characteristics. Child Psychiatry Hum Dev 2006;36(4):369-82. 